\title{
SKILL ACQUISITION THEORY AND THE ROLE OF RULE AND EXAMPLE LEARNING
}

\author{
Ilina Kachinske \\ University American College, Skopje \\ ilina.kachinske@uacs.edu.mk \\ https://orcid.org/0000-0003-3613-0395
}

The present paper presents an overview of research in support of Skill Acquisition Theory (SAT) in relation to learning a second language. Skill acquisition is defined as a gradual transition from conscious and effortful use of a cognitive skill to more automatic and fluent use of the same. As such, SAT provides a particularly insightful avenue for understanding second language development in the context of instructed second language learning. The paper focuses on the right conditions for the transition of declarative representations of second language grammar rules into procedural ones, claiming that it is only when learners have a real need for grammar rules that they become beneficial for the learner. The timing of providing grammar rules as well as the role of cognitive variables such as language learning aptitude and working memory are also addressed. Finally, future directions for explicit learning and sample second language classroom activities regarding grammar instruction are suggested.

Keywords: skill acquisition theory, declarative knowledge, procedural knowledge, explicit learning, individual differences 


\title{
ТЕОРИЈА ЗА СТЕКНУВАҢЕ ВЕШТИНИ И УЛОГАТА НА УЧЕЊЕТО ПРЕКУ ПРАВИЛО И ПРИМЕР
}

\author{
Илина Кацхинске \\ Универзитет Американ колеџ, Скопје \\ ilina.kachinske@uacs.edu.mk \\ https://orcid.org/0000-0003-3613-0395
}

Овој труд претставува преглед на истражувања што ја поткрепуваат теоријата за стекнување вештини (SAT) во контекст на изучувањето втор јазик. Стекнувањето вештини се дефинира како постепен премин од свесно и наменско користење когнитивни вештини до нивно автоматско и течно користење. Трудот се фокусира на најоптималниот начин на стекнување декларативно знаење, како и на условите што овозможуваат успешен премин на декларативните репрезентации на граматички правила од вториот јазик во процедурални. Трудот, исто така, го предочува влијанието на времето кога се даваат експлицитни граматички правила и нивната интеракција со когнитивните варијабли, какви што се надареноста за изучување втор јазик и работната меморија. На крајот се предлагаат идни насоки во врска со експлицитното учење, како и оригинални активности за едно граматичко правило.

Клучни зборови: теорија за стекнување вештини, декларативно знаење, процедурално знаење, експлицитно учење, индивидуални разлики 


\section{Introduction $^{1}$}

The question of whether grammar instruction contributes to second language (L2) development and hence whether it should be taught in a L2 classroom has been one of the most controversial questions in the field of second language acquisition (SLA) (Ellis 2008; Nassaji and Fotos 2004, 2011; Nassaji 2017). Theoretical accounts addressing questions such as when focus on form should occur in the classroom, whether grammar should be provided at the beginning, during, or only after learners have developed some initial communicative competence, or how frequently rules should be revisited in order to yield facilitative effects abound in the SLA literature (e.g., DeKeyser 1997, 1998, 2015; DeKeyser and Criado-Sanchez 2012b; Doughty and Williams 1998; N. Ellis 2002, 2005; R. Ellis 2002, 2006, 2008; Hinkel 2006; Larsen-Freeman 2009; Lightbown 1998, 2000; Long 1991, 2007, 2009; Nassaji 2011, 2017). Recent accounts on grammar generally agree that grammar teaching is an integral part of learners' ultimate attainment (e.g., Ellis 2006; Nassaji and Fotos 2004, 2011; Nassaji 2017) and thus the question is not as much whether grammar should be taught or not, but how grammar should be taught and when learners would benefit the most from grammar instruction (Kachinske and DeKeyser 2019).

The present paper provides an insight into these questions by reviewing one of the most influential cognitive theories about human learning in general and SLA in particular. Skill Acquisition Theory (SAT) accounts for how people proceed in learning a range of cognitive skills from absolute beginners to advanced learners (DeKeyser 2007a). In the sections following, the basic tenets of SAT are explained and their relevance for SLA outlined. Relevant studies are then reviewed. The paper concludes by outlining implications for teaching and sample activities.

\section{Declarative, procedural and automatized knowledge}

The basic tenet of SAT is that learning of any cognitive skill proceeds in stages starting from an initial declarative knowledge representation, which through changes in behavior leads to fluent, effortless, fast and automatic behavior. Anderson (1993) refers to these stages as declarative, procedural and automatic (Fitts and Posner 1967: cognitive, associative and autonomous; Byrne 1986: presentation, practice, production). All of these stages are characterized by fundamentally different and distinct knowledge representation. Initially, people may acquire substantial knowledge about a skill, without engaging in the behavior necessary for that skill. This knowledge may be acquired through introspective perceptual processes, but more often is transmitted through explicit verbal forms (e.g., teaching a novice learner how to drive a manual car). This declarative knowledge is then turned into a behavior by actively acting on or using the knowledge base, provided that there is a solid understanding of the declarative knowledge and memory of it at the time of proceduralization. The last stage is characterized by extensive and meaningful

\footnotetext{
${ }^{1}$ I would like to thank Varvara Nikolova for illustrating the activities in this paper.
} 
practice of the target behavior eventually leading to fluent, spontaneous and relatively error-free behavior. An in-depth account of these stages and their application in a L2 learning problem is provided in the sections following.

\subsection{Declarative knowledge}

Declarative knowledge, defined as "factual knowledge that people can report or describe", or knowledge that, is organized in chunks of declarative rules and encoded in memory (Anderson 1993: 5). It is knowledge that WW2 lasted from 1939 to 1945 or that English is a Germanic language, for instance. These rules represent a set of facts open to conscious inspection, cognitive reasoning and modification. Declarative knowledge can either be formed by means of explicit-deductive or explicit-inductive learning mechanisms. Some evidence exists to suggest that depending on the task at hand, declarative knowledge is best formed through declarative memory for examples of how procedures should be executed, i.e., behavior (Anderson and Fincham 1994; Anderson, Fincham and Douglass 1997; Taatgen and Wallach 2002). During this first stage the learner relies on declarative memory to perform a task. One benefit of representing the knowledge in declarative form is its inherent flexibility. Declarative rules do not have directionality in their statement, allowing one to use them in multiple directions, for instance interpretation and generation of a computer programming language. The downside, however, is that the application of a declarative representation is "cognitively intense and slow" (Kim et al. 2013: 25; Neves and Anderson 1981) as the learner needs to retrieve from memory the rules needed for a particular behavior. Within Anderson's ACT-R framework, declarative rules are retrieved and used through interpretative production rules, which consist of IF-THEN pairs (described below), but also refer back to the declarative rules, making them slower than the production rules (Anderson, Fincham, and Douglass 1997; Neves and Anderson 1981). In other words, each declarative rule or fact must be separately retrieved from memory, consciously interpreted and applied to the current situation.

\subsection{Proceduralized knowledge}

Once a declarative rule is applied on a regular basis and is well established, it can be compiled into a production rule, which is regarded as the unit of operation in the second and third stage of skill acquisition. During the transition between the first and the second stage, the learner starts compiling production rules, but for problematic areas still relies on declarative memory for examples or rules. These production rules constitute proceduralized knowledge and are stored in the form of IF -THEN or CONDITION-ACTION pairs. The "IF" (condition) part defines the circumstance under which the rule applies, while the "THEN" (action) part defines what should be done in that circumstance (Anderson 1993: 5). Procedural knowledge is "knowledge that people can only manifest in their performance", i.e., knowledge how to do things (Anderson 1993: 18). Common examples include how to play the piano or ride a bike. During this second, associative or transitional stage, knowledge that is transformed into knowledge how by means of extensive, but 
meaningful practice. In other words, declarative knowledge is turned into behavior guided by proceduralized knowledge (DeKeyser 2015).

As mentioned earlier, in order to execute a specific behavior when only declarative knowledge is available, the individual has to retrieve pieces of information from memory and insert them into production rules. Once proceduralization has taken place, however, production rules for a specific behavior are available to be used as chunks whenever the IF (condition) part is satisfied (DeKeyser 2007b; DeKeyser and Criado-Sánchez 2012a), eliminating the need for constant buffering of declarative knowledge in working memory. That is why procedural knowledge developed through practice can be applied more rapidly and reliably (Anderson 1993; Anderson et al., 1997).

One disadvantage of a procedural representation is that this knowledge cannot be inspected and altered. Although the learner has some understanding of the production rules' content, changes cannot be made to the productions. New productions can be created that will eventually delete or restrict the range of applicability of bad productions (Neves and Anderson 1981). In addition to this, whereas the initial declarative knowledge can be generalizable to various situations, procedural knowledge is highly specific and certainly skill-specific. It is believed that procedural knowledge is committed to a specific use and cannot generalize to other uses. For instance, practicing with a computer language in 'evaluation,' going from code to result, does not lead to the skill required for generation, going from desired result to code, and vice versa (Anderson, Fincham and Douglass 1997). This phenomenon, observed in many empirical studies, has been called the directional asymmetry that characterizes skill acquisition. It should be noted, however, that declarative and procedural knowledge are not orthogonal concepts. Both types of knowledge can coexist and interact with each other in the course of the skill development. In fact, Neves and Anderson (1981: 62) state that keeping both knowledge representations can bring the most optimal performance. "When speed is needed, the procedural encoding is used. When analysis or change is needed, the declarative encoding is used."

The final stage is the automatization of the proceduralized knowledge which is a function of the amount of practice the learner engages in. A large amount of practice is required to fully automatize the target skill which in this stage is characterized by increased speed, decreased error rate and less susceptibility to interference from other tasks.

\subsection{Right conditions for proceduralization}

Skill acquisition is defined as a gradual transition from conscious and effortful use of a cognitive skill to more automatic and fluent use of the same. Within the SAT, the processes involved in learning a second language are cognitively the same as learning any other cognitive skill, such as solving a complex mathematical problem. The starting point for both skills is the formation of declarative knowledge, which through extensive practice is proceduralized and finally automatized. This by no means suggests that some learners do not learn grammar implicitly. Implicit and explicit processes are both important in the process of learning and very often 
interact with each other in many complex ways. As mentioned later in the text, declarative knowledge can also be formed through analogy from encountered examples. It is also possible that even though learners have acquired a particular L2 grammar rule by explicit learning mechanisms, they lack the ability to verbalize those rules.

One of the most important aspects of skill acquisition, especially relevant for L2 learning, are the conditions that enable a smooth and effective transition from declarative to proceduralized knowledge representation. Theoretical literature and empirical findings suggest that there are certain prerequisite conditions essential for increasing the likelihood of successful proceduralization. First, solid and accurate declarative knowledge, either obtained deductively, by means of explicit instructions provided to the learner, or inductively, through processes of analogy and abstraction, must exist. Second, there should be plenty of opportunities for learners to apply this knowledge representation consistently. During these opportunities the declarative knowledge must be available in digestible format at the moment of executing the target behavior (DeKeyser 2007b, DeKeyser and Criado-Sánchez 2012a). This does not mean that declarative knowledge needs to be stored in longterm memory; rather it needs to be active in working memory so that it can be readily available to be turned into procedural knowledge (Anderson and Fincham 1994).

Anderson and Fincham (1994: 1323) propose that the best avenue for proceduralization is when the declarative representation is in the form of an example that is used in an analogy process. Based on their four-stage model accounting for the general course of skill acquisition, Anderson, Fincham and Douglass (1997) demonstrate that the combination of examples and declarative rules is necessary to make the transition from declarative to production rules. Their results suggest a gradual transition from example-processing to production-rule processing. Early in the learning process learners relied both on analogy to previously encountered examples and on declarative rules. With practice, the original examples and rules were slowly forgotten and asymmetric rules developed instead (see DeKeyser 1997; DeKeyser and Sokalski 1996 for asymmetry of production rules SLA). It follows that for declarative knowledge to be restructured as procedural knowledge meaningful practice is needed. Practice with feedback facilitates the process of meaningful learning rather than the learning of mechanical skills.

More empirical support comes from studies in Cognitive Psychology (CP) demonstrating that setting the right conditions for proceduralization by means of providing explicit grammar knowledge just at the moment when participants needed it, leads to more accurate and detailed knowledge (Sallas et al. 2007).

\subsection{SAT and implications for language learning}

In the field of SLA, many researchers view L2 language development, especially in classroom settings, as being similar to any other form of cognitive skill acquisition (de Jong and Perfetti 2011; DeKeyser 1997, 1998, 2001, 2007a ,b; Lyster 1994, 2004, 2007; McLaughlin 1990; Ranta and Lyster 2007; Lyster and Sato 2013). Learners in the L2 classroom typically start with declarative knowledge about L2 grammar and lexis, which through extensive practice is proceduralized and finally 
automatized. So the initial declarative knowledge is the explicit knowledge a learner has of a particular grammatical construction or vocabulary item. The procedural knowledge, on the other hand, will be the knowledge visible in a person's behavior when using the target language. During the stage of proceduralization, learners learn to rely less on their declarative knowledge and more on the production behavior they have developed through practice. Proceduralization, therefore, can be viewed as providing crutches to learners to ease the transition between completely relying on declarative rules to formulate a sentence in a L2, to using L2 grammar and lexis automatically, without having to retrieve from memory any declarative rules. As a result, cognitive resources are freed up to attend to other information online.

To illustrate with a language-specific example, declarative knowledge can consist of knowing THAT if a verb in English is regular and it needs to be used in the past, then the ending -ed is added to the regular verb and it is pronounced as $/ \mathrm{d} /$ if the verb ends in a voiced sound, as / $t /$ if the verb ends in a voiceless sound, and as $/ \mathrm{Id} /$ if the verb ends either in $d$ or $t$. Procedural knowledge, on the other hand, operates with production rules, which are behavioral rules that take the form of IF/ THEN pairs:

IF the situation to be described occurred in the past, And the verb describing the action is regular,

And the verb ends in a voiced sound,

THEN add -ed to the verb,

And pronounce it $/ \mathrm{d} /$.

As mentioned above, it is crucial for declarative knowledge to be available throughout the initial execution of the target behavior for proceduralization to take place. In instructional practice, however, very often grammar rules are presented prior to example learning or practice and are seldom revisited during the proceduralization phase, contrary to what is suggested by ACT-R.

It follows from the above that for proceduralization to take place, (a) learners should have full initial access to the declarative knowledge (the rule), (b) the rule should be comprehensible to the learner, and (c) the rule should be accessible throughout the stage of proceduralization. The further apart declarative knowledge, consisting of rules and examples, is from practice with further examples, the greater the memory decay of declarative knowledge, and the weaker the resulting procedural knowledge are expected to be. Precisely the issue of setting the right conditions for proceduralization is often overlooked in language teaching, as pointed out by DeKeyser (2007a).

In addition, according to empirical studies both in CP and SLA, practice should be skill-specific; once knowledge has been proceduralized in one skill, for instance comprehension, it becomes more difficult for that knowledge to be generalized in another skill, for example production. In other words, in order to develop receptive knowledge, learners need practice comprehending input, and in order to develop productive knowledge, learners need to practice producing language. A well-known example from research on skill acquisition is reading versus writing computer programs (Anderson 1982; Singley and Anderson 1989). Parallel findings have also been observed in the domain of comprehension and production of 
language (DeKeyser and Sokalski 1996). See Appendix 1 for sample studies that provide support for SAT.

\section{Implications for teaching}

The main implication for the language classroom is that the way declarative knowledge is formed and practiced matters for L2 development. SAT has often been misunderstood in its application for L2 learning. The mere concepts of declarative and explicit representation of knowledge or even practice seem to be automatically associated with frontal and explicit teaching of grammatical structures and lexis and thus often eschewed by applied linguists. Observations of traditional foreign-language classrooms attest to this misconception: the most common progression of an L2 class takes the form of the well-known P-P-P (present, practice, produce). While SAT theory clearly specifies that declarative knowledge is the starting point for any skill acquisition, it does not prescribe concrete steps as to how this declarative knowledge should be presented. It is up to the practitioner, or the L2 teacher in our case, to discern the most adequate way of presenting. Empirical results do show, however, that the best avenue for the formation of declarative knowledge is not through deductive presentation, but rather through examples situated in meaningful contexts (Kachinske and DeKeyser 2019; Sallas et al. 2007)

If we accept that the initial formation of rules and word-meaning mapping of new lexis is best achieved when there is a real need for them and when learners are psychologically ready to learn, then what impetus does a learner have to pay attention to and remember the rules for past simple regular and irregular verbs, or the meaning of the word "lugubrious" if they are presented with them in isolation at the beginning of a class? The answer is straightforward: none! When rules and new lexis, however, are substantiated in examples or tasks whose understanding and completion hinges upon the declarative representation of the same, then there is a real need and motivation for learners to pay attention to those rules and subsequently use them. It is only when the right conditions are in place that the explicit grammar rules become beneficial for the learners. In this way the problem-solving process does not overburden our limited working memory capacity, and the attentional resources are freed for the required proceduralization of declarative knowledge. Pedagogical observations to the same effect have also been made, suggesting that the best time to provide learners with grammar rules or error correction is precisely at the moment when learners are negotiating for meaning and need the linguistic information to get their meaning across appropriately and accurately (Long 1991).

The role of the teacher then shifts from explicitly teaching to providing data upon which the learners' focal attention will operate. This task is certainly not an easy one. How should an L2 teacher decide upon the most adequate way of strengthening form-meaning mappings of specific structures? Having read the relevant theoretical and empirical research in the field, they would soon realize that there isn't any one theory or methodological approach that would be suitable for all of their students and all the structures that need to be taught. Understanding the literature would only help them choose the right presentation or practice for specific students and specific structures at a given time. The decisions would depend on a 
variety of factors known to interact with language acquisition: (1) the situation in which the L2 is learned (second, foreign, heritage language learning), (2) immersion or traditional L2 classroom, (3) the age of the learners, (4) the natural cognitive endowment of each learner (e.g., high-low aptitude, aptitude for implicit vs. explicit learning, high-low working memory) as well as (5) the complexity, salience and difficulty of the target structure, just to name some.

The age of the learners is especially determinative when decisions about presentation and practice need to be made. Given young learners' aptitude and propensity for implicit learning (DeKeyser 2000, 2003; DeKeyser and Larson-Hall 2005; Ellis 2005, 2009; Muñoz 2006; Paradis 2004, 2009; Ullman 2001), teachers should aim at fostering opportunities in the L2 classroom for such learning to occur. These opportunities can take the form of a creative, meaningful and incidental instruction whereby grammar structures and vocabulary arise naturally from the context. This doesn't exclude adopting such a belief when it comes to adult L2 learners. On the contrary, the psychological benefits are manifold across a range of ages. For one, couching grammar presentations in a meaningful context can serve as a motivating factor for learners to be attentive to the material being presented. By now, the role of attention has been established as a crucial factor for learning: what is attended to, is learned (Ellis and Robinson, 2008; Schmidt, 1990). Next, as discussed earlier, the nature of the contextualized presentation provides learners with a real need to learn and subsequently apply the rules. Last, in view of mounting empirical results pointing to the role of language aptitude and working memory capacity as strong and significant predictors of SLA (e.g. Brooks, Kempe, and Sionov 2006; Erlam 2005; Li 2013; Perrachione, Lee, Ha and Wong 2011; Robinson 1997; Sheen 2007; Wesche 1981, French and O'Brien 2008; Goo 2012; Juffs 2004; Juffs and Harrington 2011; Kormos and Safar 2008; Linck et al. 2013; Mackey, Adams, Stafford and Winke 2010; Martin and Ellis 2012; O'Brien Segalowitz, Collentine and Freed 2006; Révész 2012; Williams 1999; Williams and Lovatt 2003), this view can accommodate a variety of language learning aptitude and working memory profiles. The contextualized examples are created in such a way that they arise and stand out naturally from the context. For high aptitude learners this means that the chances for inducing rules are maximized. For low aptitude learners it means that when the teacher eventually provides the rules, they are not decontextualized, but rooted in meaningful activities. Similarly, once rules arise, learners with low working memory capacity have the advantage of constantly applying those rules through practice by having the rules provided for them when needed. Similarly, learners with lower working memory capacity will benefit more if rules are presented concurrently with practice when they are really needed (Kachinske and DeKeyser 2019).

This brings us to the second point: practice within SAT. The second misapplication of SAT is the use of "drill until you kill" type of practice, or the use of mechanical drills in an L2 language classroom. Observations of this kind are not rare in the literature. Bange, Carol and Griggs (2005), for instance, observed a tendency in L2 classrooms to develop primarily declarative knowledge and urged L2 teachers to provide more opportunities for contextualized and meaningful practice. Anderson (2005) also speaks of meaningful and elaborative processing as more effective in that it is better in engaging the brain processes required for successful recall. 
Traditional practice includes a variety of drills, translation, as well as repetition tasks. Despite calls to abandon these drills, L2 teachers still resort to such practices, which is one reason why many applied linguists eschew this term. Gatbonton and Segalowitz (2005), for instance, report that when teachers believed students needed more practice, they turned to non-communicative drills. Mechanical drills serve no purpose in transitioning from the declarative to the procedural stage. They engage the learner in mechanically practicing target structures and not in conveying meaning through language. Hence, no form-meaning mapping is established. Rather, forms are mechanically linked to other forms, without even drawing on declarative knowledge. Simple analogy between items suffices for the completion of these items. To bridge the gap between form and meaning, many researchers have proposed the use of meaningful and communicative drills or activities. Meaningful refers to the concurrent focus on and processing of both form and meaning and cannot be completed without a full understanding of its structure and semantics (DeKeyser 2007; Ortega 2007). A genuinely communicative activity, on the other hand, involves "at least two participants working together to complete a task by exchanging information processed by one and not the other (Gatbonton and Segalowitz 2005: 331). These activities engage the learner in conveying meaningful information while practicing a target structure. The form and its meaning are never dissociated, rather, they are brought together by the nature of the task. Information gap activities have become the epitome of genuinely communicative practice.Finally, it should be highlighted that both types of knowledge representation should be fostered in the classroom: "highly specific procedural knowledge, highly automatized for efficient use in the situations that the learner is most likely to confront in the immediate future, and solid abstract declarative knowledge that can be called upon to be integrated into much broader, more abstract, procedural rules" (DeKeyser 2015). See Appendix 2 for sample activities illustrating an incidental presentation and meaningful practice of an L2 grammar rule.

\section{Concluding remarks}

The present paper provided an overview of the main tenets of Skill Acquisition Theory, as one of the most influential theories about human learning in general, and learning a second language in particular. While any skill acquisition is founded on a solid representation of declarative knowledge, the issue of how this declarative knowledge is obtained is an important one when it comes to learning a second language grammar rule. Taking into account results from empirical studies in cognitive psychology and second language acquisition, as well as the role of individual differences such as language learning aptitude and working memory, it was suggested that the best avenue for the formation of declarative knowledge is through contextualized and meaningful examples rather than in isolation. Grammar rules are beneficial to the learner only when there is a real need for them. It was further claimed that the incidental and meaningful presentation of grammar rules gives a chance to individuals with high language learning aptitude to induce the rules for themselves. The reviewed theoretical and empirical literature, then, is most supportive of the notion that not only are both top-down (rules) and bottom-up (exam- 
ples) processes essential for the development of accurate L2 grammar knowledge, but that it is also important how and when these processes are integrated. Bearing this in mind, the starting point should always include contextualized examples, followed by rule presentation with additional examples and meaningful practice.

\section{Bibliography}

Anderson, J. R. (1982). Acquisition of cognitive skill. Psychological review, 89(4), 369.

Anderson, J. R. (1993). Rules of the mind: Routledge.

Anderson, J. R. (2005). Human symbol manipulation within an integrated cognitive architecture. Cognitive Science, 29, 313-342.

Anderson, J. R., and Fincham, J. M. (1994). Acquisition of procedural skills from examples. Journal of experimental psychology: learning, memory, and cognition, 20(6), 1322.

Anderson, J. R., Fincham, J. M., and Douglass, S. (1997). The role of examples and rules in the acquisition of a cognitive skill. Journal of Experimental Psychology: Learning, Memory, and Cognition, 23(4), 932.

Brooks, P. J., Kempe, V., and Sionov, A. (2006). The role of learner and input variables in learning inflectional morphology. Applied Psycholinguistics, 27(02), 185-209.

Byrne, D. (Ed.). (1986). Teaching oral English (2nd ed.). Harlow, England: Longman.

De Jong, N. (2005). Can second language grammar be learned through listening?: An experimental study. Studies in Second Language Acquisition, 27(02), 205-234.

De Jong, N., and Perfetti, C. A. (2011). Fluency training in the ESL classroom: An experimental study of fluency development and proceduralization. Language Learning, 61(2), 533-568.

DeKeyser, R. M. (1997). Beyond explicit rule learning. Studies in Second Language Acquisition, 19(02), 195-221.

DeKeyser, R. M. (1998). Beyond focus on form: Cognitive perspectives on learning and practic- ing second language grammar. In C. D. J. Williams (Ed.), Focus on form in classroom second language acquisition (pp. 42-63). Cambridge, England: Cambridge University Press.

DeKeyser, R. M. (2000). The robustness of critical period effects in second language acquisition. Studies in Second Language Acquisition, 22(04), 499-533.

DeKeyser, R. M. (2003). Implicit and explicit learning. In C. Doughty and M. Long (Eds.), Handbook of Second Language Acquisition (pp. 313-348). Oxford, UK: Blackwell.

DeKeyser, R. M. (2007a). Skill acquisition theory. Theories in second language acquisition, $97-113$.

DeKeyser, R. M. (2007b). (Ed.). Practice in a second language: Perspectives from applied linguistics and cognitive psychology. New York: Cambridge University Press.

DeKeyser, R. M. (2012). Interactions Between Individual Differences, Treatments, and Structures in SLA. Language Learning, 62(s2), 189-200.

DeKeyser, R. M. (2015). Skill Acquisition Theory. In B. VanPatten and J. Williams (Eds.), Theories in Second Language Acquisition: An Introduction (pp. 94-113). New York: Routeledge.

DeKeyser, R. M., and Sokalski, K. J. (1996). The differential role of comprehension and production practice. Language Learning, 46(4), 613-642.

DeKeyser, R. M., and Criado-Sánchez, R. (2012a). Automatization, skill acquisition, and practice in second language acquisition. . In C. A. Chapelle (Ed.), The Encyclopedia of Applied Linguistics (pp. 323-331). Oxford, UK: Wiley-Blackwell. 
DeKeyser, R. M., and Criado-Sánchez, R. (2012b). Practice in second language instruction. In C. A. Chapelle (Ed.), The Encyclopedia of Applied Linguistics (pp. 4501-4504). Oxford, UK: Wiley-Blackwell.

Doughty, C., and Williams, J. (1998). Pedagogical choices in focus on form. Focus on form in classroom second language acquisition, 197-261.

Ellis, N.C. (2002). Frequency effects in language processing. Studies in Second Language Acquisition, 24(2), 143-188.

Ellis, N. C. (2005). At the interface: Dynamic interactions of explicit and implicit language knowledge. Studies in Second Language Acquisition, 27(2), 305-352.

Ellis, N. C., and Robinson, P. (2008). An introduction to cognitive linguistics, second language acquisition, and language instruction (pp. 13-34). Routledge.

Ellis, R. (2002). Grammar teaching: Practice or consciousness-raising. Methodology in language teaching: An anthology of current practice, 167, 174.

Ellis, R. (2006). Current issues in the teaching of grammar: An SLA perspective. TESOL quarterly, 40(1), 83-107.

Ellis, R. (2008). 31 Explicit Form-Focused Instruction and Second Language Acquisition. The handbook of educational linguistics, 437.

Erlam, R. (2005). Language aptitude and its relationship to instructional effectiveness in second language acquisition. Language Teaching Research, 9(2), 147-171.

Fitts, P., and Posner, M. (1967). Human performance. Belmont, CA: Brooks/Cole.

French, L. M. and O'Brien, I. (2008). Phonological memory and children's second language grammar learning. Applied Psycholinguistics, 29, 463-87.

Gatbonton, E., and Segalowitz, N. (2005). Rethinking communicative language teaching: A focus on access to fluency. Canadian Modern Language Review, 61(3), 325-353.

Goo, J. ( 2012 ). Corrective feedback and working memory capacity in interaction-driven L2 learning. Studies in Second Language Acquisition, 34, 445 - 474.

Hinkel, E. (2006). Current perspectives on teaching the four skills. TESOL Quarterly, 40(1), 109-131.

Juffs, A. (2004). Representation, processing and working memory in a second language. Transactions of the Philological Society, 102, 199-226.

Juffs, A. and Harrington, M.W. (2011). Aspects of working memory in L2 Learning. Language Teaching: Reviews and Studies, 42 (2), 137-166.

Williams, J. (1999). Learner generated attention to form. Language learning, 49(4), 583625.

Kachinske, I., and DeKeyser, R. (2019). The interaction between timing of explicit grammar explanation and individual differences in second language acquisition. Journal of Second Language Studies, 2(2), 197-232.

Kim, J. W., Ritter, F. E., and Koubek, R. J. (2013). An integrated theory for improved skill acquisition and retention in the three stages of learning. Theoretical Issues in Ergonomics Science, 14(1), 22-37.

Kormos, J., and Sáfár, A. (2008). Phonological short-term memory, working memory and foreign language performance in intensive language learning. Bilingualism: Language and Cognition, 11(2), 261-271.

Larsen-Freeman, D. (2009). 27 Teaching and Testing Grammar. The handbook of language teaching, 518.

Li, S. (2013). The interactions between the effects of implicit and explicit feedback and individual differences in language analytic ability and working memory. The Modern Language Journal, 97(3), 634-654.

Linck, J. A., Hughes, M. M., Campbell, S. G., Silbert, N. H., Tare, M., Jackson, S. R., Doughty, C. J. (2013). Hi-LAB: A New Measure of Aptitude for High-Level Language Proficiency. Language Learning, 63(3), 530-566. 
Lightbown, P. M. (1998). The importance of timing in focus on form. In C. Doughty and J. Williams (Eds.), Focus on form in classroom second language acquisition (pp. 114138). Cambridge: Cambridge University Press.

Lightbown, P. M. (2000). Anniversary article. Classroom SLA research and second language teaching. Applied linguistics, 21(4), 431-462.

Long, M. H. (1991). Focus on form: A design feature in language teaching methodology. Foreign language research in cross-cultural perspective, 2, 39-52.

Long, M. H. (2007). Second and foreign language education. In Mathinson, S., and Ross, W. (eds.), Battleground schools: An encyclopedia of conflict and controversy (pp. 24954). Westport, CT: Greenwood Press.

Long, M. H. (2009). Methodological principles for language teaching. In Long, M. H. and Doughty, C. J. (eds.), Handbook of language teaching (pp. 373-94). Oxford: Blackwell.

Lyster, R., and Sato, M. (2013). Skill acquisition theory and the role of practice in L2 development. In M. García Mayo, J. Gutierrez-Mangado and M. Martínez Adrián (Eds.), Multiple perspectives on second language acquisition. Amsterdam: Benjamins.

Lyster, R. (1994). The effect of functional-analytic teaching on aspects of French immersion students' sociolinguistic competence. Applied Linguistics, 15(3), 263-287.

Lyster, R. (2004). Research on form-focused instruction in immersion classrooms: Implications for theory and practice. Journal of French Language Studies, 14, 321-341.

Lyster, R. (2007). Learning and teaching languages through content: A counterbalanced approach. Amsterdam: Benjamins.

Mackey, A., Adams, R., Stafford, C., and Winke, P. (2010). Exploring the relationship between modified output and working memory capacity. Language Learning, 60(3), 501533.

Martin, K. I., and Ellis, N. C. (2012). The Roles of Phonological STM and Working Memory in L2 Grammar and Vocabulary Learning. Studies in Second Language Acquisition, 34 (3), 379-413.

McLaughlin, B. (1990). Restructuring. Applied Linguistics, 11(2), 113-128.

Muñoz, C. (2006). The effects of age on foreign language learning: The BAF project. In Age and the rate of foreign language learning (pp. 1-40). Multilingual Matters.

Nassaji, H. (2017). Grammar acquisition. In The Routledge handbook of instructed second language acquisition (pp. 205-223). Routledge.

Nassaji, H., and Fotos, S. (2004). 6. Current developments in research on the teaching of grammar. Annual review of applied linguistics, 24, 126-145.

Nassaji, H., and Fotos, S. S. (2011). Teaching grammar in second language classrooms: Integrating form-focused instruction in communicative context. Routledge.

Neves, D. M. and Anderson, J. R. (1981). Knowledge Compilation: Mechanisms for the Automatization of Cognitive Skills. In J. R. Anderson (Ed.), Cognitive Skills and Their Acquisition, (pp. 57-84). Hillsdale, NJ: Erlbaum.

O'Brien, I., Segalowitz, N., Collentine, J., and Freed, B., (2006). Phonological memory and lexical, narrative, and grammatical skills in second language oral production by adult learners. Applied Psycholinguistics, 27, 377-402.

Ortega, L. (2007). Meaningful L2 practice in foreign language classrooms: A cognitive-interactionist SLA perspective. In R. DeKeyser (Author), Practice in a Second Language: Perspectives from Applied Linguistics and Cognitive Psychology( Cambridge Applied Linguistics, pp. 180-207). Cambridge: Cambridge University Press. doi:10.1017/ CBO9780511667275.011

Paradis, M. (2004). A neurolinguistic theory of bilingualism (Vol. 18). John Benjamins Publishing.

Paradis, M. (2009). Declarative and procedural determinants of second languages (Vol. 40). John Benjamins Publishing. 
Perrachione, T. K., Lee, J., Ha, L. Y., and Wong, P. C. (2011). Learning a novel phonological contrast depends on interactions between individual differences and training paradigm design. The Journal of the Acoustical Society of America, 130(1), 461-472.

Ranta, L., and Lyster, R. (2007). A cognitive approach to improving immersion students' oral production abilities: The awareness, practice, and feedback sequence. In R. DeKeyser (Ed.), Practicing in a second language: Perspectives from applied linguistics and cognitive psychology. New York: Cambridge University Press.

Révész, A. (2012). Working memory and the observed effectiveness of recasts on different L2 outcome measures. Language Learning 62 (1), 93-132.

Robinson, P. (1997). Generalizability and automaticity of second language learning under implicit, incidental, enhanced, and instructed conditions. Studies in Second Language Acquisition, 19(02), 223-247.

Rodgers, D. M. (2011). The automatization of verbal morphology in instructed second language acquisition. IRAL-International Review of Applied Linguistics in Language Teaching, 49(4), 295-319.

Sallas, B., Mathews, R. C., Lane, S. M., and Sun, R. (2007). Developing rich and quickly accessed knowledge of an artificial grammar. Memory and cognition, 35(8), 2118-2133.

Schmidt, R. (1990). The Role of Consciousness in Second Language Learning. Applied Linguistics, 11(2), 129-158.

Sheen, Y. (2007). The effect of focused written corrective feedback and language aptitude on ESL learners' acquisition of articles. TESOL Quarterly, 41(2), 255-283.

Singley, M. K., and Anderson, J. R. (1989). The transfer of cognitive skill (No. 9). Harvard University Press.

Taatgen, N. A., and Wallach, D. (2002). Whether skill acquisition is rule or instance based is determined by the structure of the task. Cognitive Science Quarterly, 2(2), 163-204.

\section{Appendix 1: Empirical evidence for SAT in the field of SLA}

Very little research in the area of SLA has explicitly set out to investigate the applicability of skill acquisition theory to L2 learning (DeKeyser 2015). While several very important questions have been addressed so far, the issues of the timing, availability, and precise role of declarative knowledge, as well as the exact relationship between rules and examples that produces the most optimal learning have not been thoroughly investigated in SLA.

Evidence for the skill-specificity phenomenon comes from DeKeyser (1997), De Jong (2005) and Rogers (2011). They both demonstrated that extensive training in comprehension did not prevent errors in production. DeKeyser (1997) conducted a longitudinal study over eleven weeks which included both production and comprehension exercises. Upon receiving explicit instructions of the target grammatical rule, the subjects either performed a production or comprehension task. Apart from confirming that gradual skill automatization occurred as a result of the practice, the results also indicated that practice was skill-specific. Students who practiced through comprehension improved their comprehension skills, and vice versa, the ones that received production practice bettered their production skills. Similar findings are reported by De Jong (2005) who investigated the impact of aural comprehension training on the development of both comprehension and production skills of the target structures. While increased processing speed was observed in comprehension, this specific training did not aid learners' skill in producing the 
target structures. Rogers (2011) demonstrated that the proceduralization of verbal morphology was achieved through practice, but less so in production than in comprehension.

Focusing on the stage of proceduralization, De Jong and Perfetti (2011) investigated fluency development and the underlying changes of knowledge representation as a function of practice. Using the $4 / 3 / 2$ / task which engages learners in a speaking activity for 4, 3 and then 2 minutes, learners were able to increase their fluency. More importantly, only those learners who repeated their speeches several times were able to transfer their fluency to a speech about a new topic. Proceduralization in the form of repetition of particular words and sentence structures was essential for the increase in fluency.

Finally, a more recent study by Kachinske \& DeKeyser (2019) investigated the extent to which grammar explanation (GE) before practice, grammar explanation during practice, and individual differences impact the acquisition of L2 declarative and procedural knowledge of two grammatical structures in Spanish. In their experiment, 128 English-speaking learners of Spanish were randomly assigned to four experimental treatments and completed comprehension-based task-essential practice for interpreting object-verb (OV) and ser/estar (SER) sentences in Spanish. Results confirmed the predicted importance of timing of GE: participants who received GE during practice were more likely to develop and retain their knowledge successfully. Results further revealed that the various combinations of rules and practice posed differential task demands on the learners and consequently drew on language aptitude and working memory to a different extent. Since these correlations between individual differences and learning outcomes were the least observed in the conditions that received GE during practice, the authors found that the suitable integration of rules and practice ameliorated task demands, reducing the burden on the learner, and accordingly mitigated the role of participants' individual differences. Finally, some evidence also showed that the comprehension practice that participants received for the two structures was not sufficient for the formation of solid productive knowledge, but was more effective for the OV than for the SER construction. Taken together, results suggest that higher-level grammatical knowledge provided just when participants need it produces more accurate and detailed knowledge, which is reminiscent of our discussion above that the declarative knowledge and the tasks used to utilize this knowledge should be close together for proceduralization to be effective.

\section{Appendix 2: Sample rule presentation and practice activities}

In a traditional L2 classroom, rules are usually presented at the beginning of a class, explicitly and in isolation. For instance, if we take adult L2 learners of English as a foreign language and the formation of past simple in English, the presentation may proceed as follows:

Teacher: Today we are going to learn about Past Simple of regular verbs in English. Past Simple in English is formed by adding the suffix -ed to (the stem of) the verb. Here are some regular verbs in English: play - played, stay - stayed, workworked, start-started. 
Repeat after me:

Teacher: Yesterday, I worked at home.

Students: Yesterday, I worked at home.

Teacher: play.

Students: Yesterday, I played at home.

Teacher: stay.

Students: Yesterday, I stayed at home.

Teacher: Now, let's try and put these verbs in past simple tense.

a. Tom to the park yesterday (walk)

б. Ann video games the previous night (play)

When the concept of teaching is not equated with explicit teaching, then there is room for more creative ways of presenting grammar. The following story is one way of presenting the formation of the past simple tense of regular verbs in English in an incidental way. The grammar rule is contextualized in a story about a character (photo, puppet, drawing on the board) and is encountered several times throughout the story. In other words, learners are exposed to target rules in a meaningful and contextualized way. This kind of incidental presentation allows for high aptitude learners to infer the rules from the context, and for low aptitude learners to be primed before they are presented with the rule. The presentation of the rule has risen naturally out of the meaningful context. Other rules related to past simple tense, such as question formation and negation can easily be added in the activities relating to our character.

This is Clever Camel (authentic children's literature provides a wealth of resources for teaching L2). He lives in Pickle Town. He is the one who always makes clever choices and the whole town depends on his brains. Usually, he starts his day by having a hot, homemade meal, but yesterday he started his day differently. He skipped breakfast. Not a clever choice. He was so hungry he needed to stop by his neighbor, Accusing Alligator. Of course, Accusing Alligator accused Clever Camel of not having breakfast. In the afternoons, Clever Camel usually works in his garden, but yesterday he worked in the park. He decided to be useful for his town and picked up all of the trash being left out. Usually, Clever Camel spends his evenings preparing his food for the next day, as in the end he is Clever Camel. But yesterday, being so tired, he watched TV for two hours straight.

Next, comes the stage of proceduralization, which requires conscious practicing of the declarative knowledge situated in meaningful activities. At this point the teacher can write the rule on the board so that learners who haven't abstracted it or the ones who have low working memory can have the rule in front of them. Instead of substitution and repetition drills, this stage can take the form of continuing the story by including new actions. The teacher can supply verbs in the base form and ask students to work in pairs or groups to expand the story.

Following the presentation of the various stories, students receive an information gap activity which is performed either in pairs or groups. List A includes 6 activities that Clever Camel did the previous day, but not in a chronological order. List B includes additional 6 activities not present in List A. The goal is for students 
to work together and recreate what Clever Camel did on a specific day. These activities were created by the author of this paper.

\section{List A}

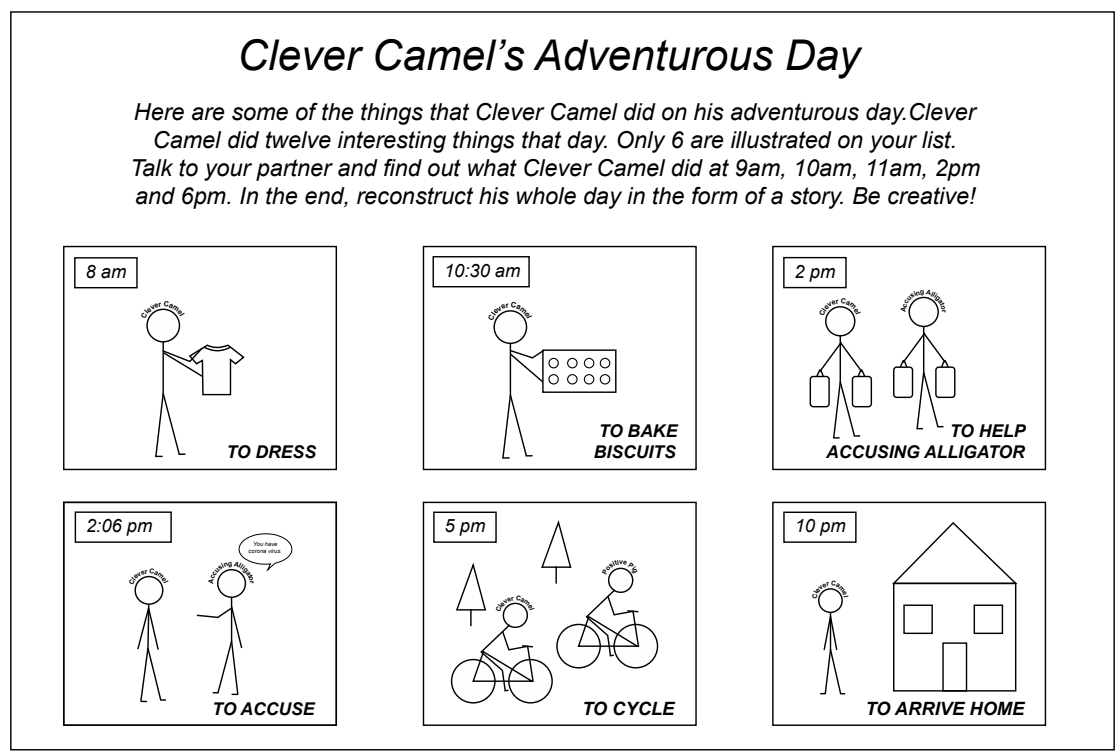

\section{List B}

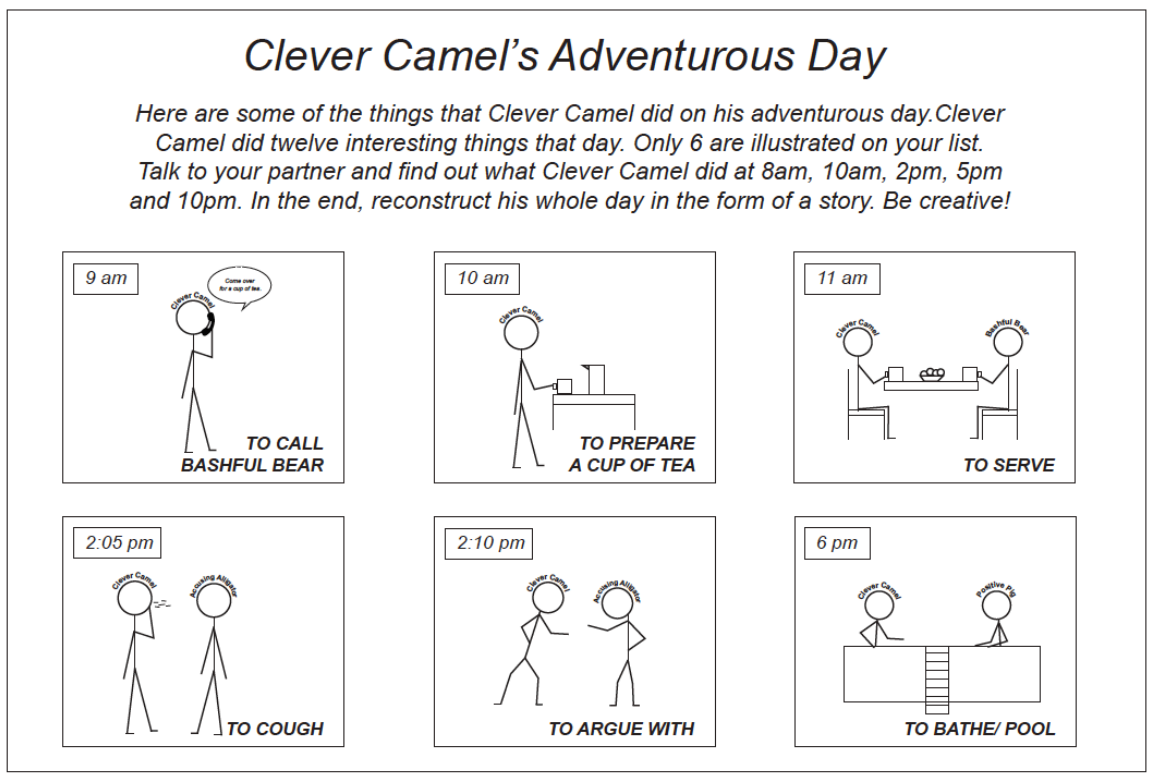


